\title{
Full-thickness gaping wound in the inguinal region of prenatal origin in an extremely premature baby
}

\author{
Satyaranjan Pegu, Poornima Murthy
}

Department of Pediatrics, Division of Neonatology, Regina General Hospital, Regina Qu'Appelle Health Region, Regina, Saskatchewan, Canada

\section{Correspondence to} Dr Satyaranjan Pegu, satyapegu@gmail.com

Accepted 3 May 2017
To cite: Pegu S, Murthy P. BMJ Case Rep Published Online First: [please include Day Month Year]. doi:10.1136/bcr-2017220402

\section{DESCRIPTION}

This baby boy weighing $810 \mathrm{~g}$ at birth was born at 24 $6 / 7$ weeks to a healthy primigravida with uncomplicated pregnancy until 24 weeks. She was hospitalised from 24 weeks' gestation onwards for threatened preterm labour. Serial bedside ultrasound showed the baby to be in a breech position with bulging membranes and a visible loop of umbilical cord within the cervical os. About 48 hours prior to delivery, there was some leaking of amniotic fluid indicating possible rupture of membranes. She was not in active labour apart from intermittent contractions. Elective caesarean section was done for concerns with cord prolapse. Delivery was unremarkable with no surgical trauma or traction to the leg as confirmed by the obstetrician. The infant was resuscitated per protocol and transferred to the neonatal intensive care unit. At birth, the baby was found to have a full-thickness deep gaping wound in the right inguinal region measuring about $5 \mathrm{~cm}$ long, $3 \mathrm{~cm}$ wide and about $1 \mathrm{~cm}$ deep (figure 1). Deep fascia, as well as some blood vessels, was visible. A clot was also noticed at the site. Apart from some serosanguinous discharge, there was no fresh bleeding. Characteristics of the wound also suggested that it was a tear/laceration probably caused by stretching/pressure on the fragile skin of the baby because of the position of the limb or

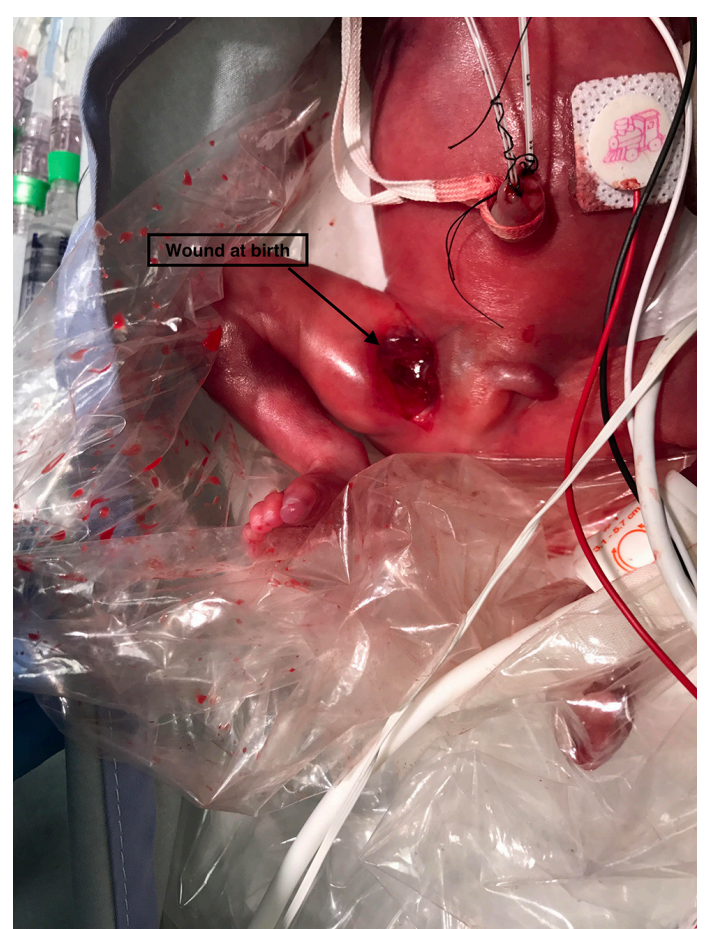

Figure 1 Wound in the right inguinal region at birth.

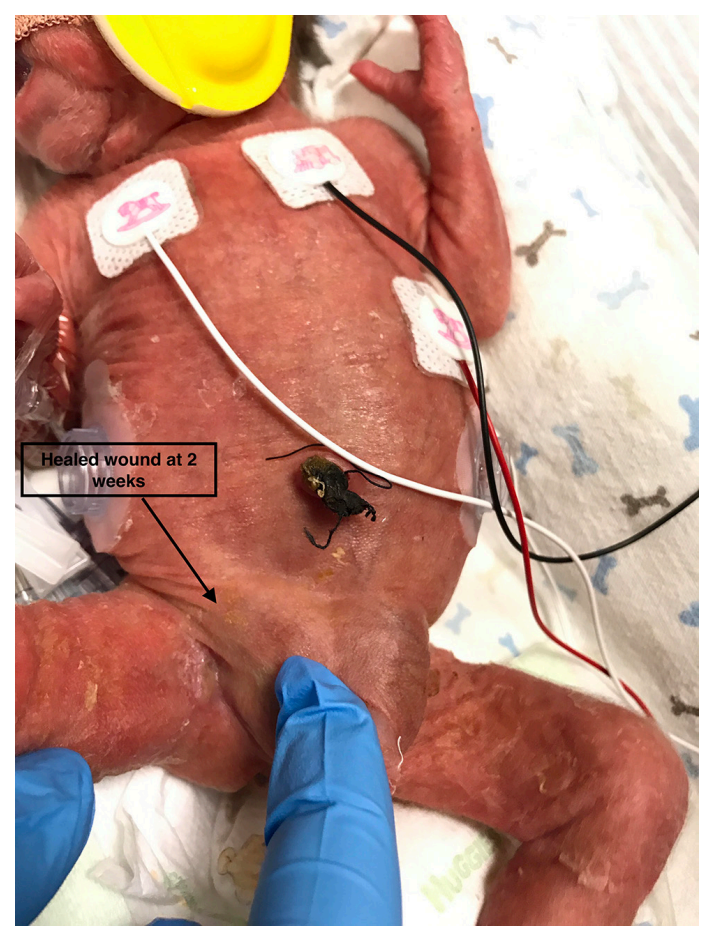

Figure 2 Healed wound at 2 weeks.

pressure on that area against the uterus or maternal pelvic bones or an unknown cause. Both paediatric and plastic surgeons recommended only conservative management. Regular normal saline irrigation, Mepilex transfer, gauze and securement with a maintenance of strict asepsis resulted in healing within the next 10-14 days (figure 2). No local antisepsis was required. The baby received 5 days of systemic antibiotics in view of preterm labour.

Reports of ulcers or skin damage at birth have been described in the literature. It could be due to the pressure of the maternal structures on the baby or an unknown cause leading to the development of ulcers or skin damage which are not picked up while in utero but noted at birth. ${ }^{1}$

The epidermis and dermis of a growing fetus exhibit clear architectural arrangement by 4 months' gestation, although the stratum corneum is still underdeveloped and minimally functional. ${ }^{2}$ Hence, babies born at 24 weeks of gestation have an extremely fragile immature epidermis with red, translucent, gelatinous appearance. In addition, lack of subcutaneous tissue causes their dermis to lie directly over the muscle. Even accidental skin stripping secondary to adhesive dressing or tape removal could result in full-thickness tissue loss. The visualisation of fascia and blood vessels in this baby's wound indicates this fragile and delicate architecture. Fortunately, wounds 


\section{Learning points}

- Stretching/pressure, dependent position or unknown causes could cause tear of the fragile skin and surrounding tissues in the extremely premature babies.

- Sterile dressing and vigilant monitoring for local infection would suffice for healing in such cases.

- Wounds in neonates and children usually exhibit faster rates of healing than adults.

in neonates and children usually exhibit faster rates of healing (as noted in our case) due to the greater content of fibroblasts, more rapid production of collagen and elastin and faster granulation tissue formation when compared with adults. ${ }^{3}$
Contributors SP was involved in the care of the patient and drafted the manuscript. PM was involved in the patient's care, revised and approved the final manuscript.

Competing interests None declared.

Patient consent Obtained.

Provenance and peer review Not commissioned; externally peer reviewed.

(c) BMJ Publishing Group Ltd (unless otherwise stated in the text of the article) 2017. All rights reserved. No commercial use is permitted unless otherwise expressly granted.

\section{REFERENCES}

1 Irving V. Wound care for preterm neonates. Infant 2006;2:102-6.

2 Dyer JA. Newborn skin care. Semin Perinatol 2013;37:3-7.

3 Baharestani MM. An overview of neonatal and pediatric wound care knowledge and considerations. Ostomy Wound Manage 2007;53:34-6.

Copyright 2017 BMJ Publishing Group. All rights reserved. For permission to reuse any of this content visit http://group.bmj.com/group/rights-licensing/permissions.

BMJ Case Report Fellows may re-use this article for personal use and teaching without any further permission.

Become a Fellow of BMJ Case Reports today and you can:

- Submit as many cases as you like

Enjoy fast sympathetic peer review and rapid publication of accepted articles

- Access all the published articles

Re-use any of the published material for personal use and teaching without further permission

For information on Institutional Fellowships contact consortiasales@bmjgroup.com

Visit casereports.bmj.com for more articles like this and to become a Fellow 